\title{
Prevalence of gonorrhoea in prostitutes in a Central African town
}

\author{
A. MEHEUS, A. DE CLERCQ, AND R. PRAT \\ Departments of Social Medicine, Gynaecology and Medical Microbiology, \\ Université Nationale du Rwanda, Butare, Rwanda
}

All observers agree upon the high frequency of gonorrhoea in tropical Africa, but also mention the lack of precise data on the disease. Research has been carried out during the last decade in some Englishspeaking countries of Africa. In Uganda Bennett (1962) and Kibukamusoke (1965) studied the disease in the general population, Arya and Bennett (1967) in university students, and Ongom (1970) in military communities. Social factors were investigated by Bennett (1962) and Ongom, Lwanga, Mugisha, and Mafigiri (1971). Verhagen and Gemert (1972) studied social and epidemiological aspects of gonorrhoea in Kenya. In an attempt to study the epidemiology of gonorrhoea in Rwanda, we have investigated student and military populations (Meheus, 1973).

Most of the above studies emphasize the importance of prostitution in transmitting the disease. The aim of the present study was to determine the prevalence of gonorrhoea in a population of prostitutes in Africa.

\section{Material and methods}

Prostitutes working in local bars or at their homes were listed in the town of Butare, which is the second town of the country and has 10,000 inhabitants; the work was done by social workers of the National Health Institute, Butare, in cooperation with the local authorities and barkeepers.

From a list of 293 prostitutes, the so called femmes libres, 100 were selected at random and invited to undergo a medical examination at the Institute.

Name, age, residence, place of work (hotel, bar, home), and registration number at the venereal disease clinic of the Institute were noted. Symptoms of dysuria, low abdominal pain, and vaginal discharge were routinely enquired after.

All prostitutes had a complete pelvic examination. Specimens for culture, taken with a sterile cotton-tipped applicator from the urethra, vagina, and cervix, were immediately put onto Thayer-Martin medium and reached the laboratory within 1 hour. After 1 night's

Received for publication April 30, 1973

Address for reprints: Dr A. Meheus, Institut National de Santé, BP 68, Butare, Rwanda incubation in a candle-extinction jar, the cultures were examined; suspected colonies were tested for oxidase reaction and examined microscopically after Gramstaining. If oxidase-positive Gram-negative diplococci were found, the identification was confirmed by sugar fermentation reactions (glucose, maltose, saccharose).

The prostitutes who would not attend for examination were again visited by a social worker who tried to persuade them to attend.

\section{Results}

Table I gives the age distribution of the 86 prostitutes examined; only 2 per cent. were aged 30 years or more, 86 per cent. being between 15 and 25 years old. The mean age was 21.2 years, 20.8 years for the gonorrhoea-positive cases and 21.6 years for the negative cases.

TABLE I Age distribution of prostitutes examined

\begin{tabular}{|c|c|c|}
\hline Age group (yrs) & No. of subjects & Percentage \\
\hline $\begin{array}{l}15-19 \\
20-24 \\
25-29 \\
30 \text { and more }\end{array}$ & $\begin{array}{r}38 \\
36 \\
10 \\
2\end{array}$ & $\begin{array}{r}44 \\
42 \\
12 \\
2\end{array}$ \\
\hline All ages & 86 & 100 \\
\hline
\end{tabular}

In the random sample of 100 , the initial response rate was 77 per cent.; 39 had positive cultures for the gonococcus-a prevalence rate of 50.6 per cent.

When the 23 who did not respond at first were again invited to attend for examination, nine prostitutes came forward, and five were found to have gonorrhoea. This suggests that the prevalence of 50.6 per cent. is not much biased by nonresponse.

Altogether, 86 out of the random sample of 100 were examined and on the basis of one set of cultures a prevalence rate of $51 \cdot 2$ per cent. was established (Table II, opposite).

Table III shows the incidence of certain symptoms (dysuria, low abdominal pain, and vaginal discharge) in the infected and non-infected prostitutes. 
TABLE II Prevalence of gonorrhoea in a random sample of 100 prostitutes

\begin{tabular}{|c|c|c|c|c|}
\hline \multirow[b]{2}{*}{ Series } & \multirow[b]{2}{*}{ Total cases } & \multirow{2}{*}{$\begin{array}{l}\text { No. } \\
\text { examined }\end{array}$} & \multicolumn{2}{|c|}{ Gonorrhoea } \\
\hline & & & No. & Per cent. \\
\hline $\begin{array}{l}\text { Ramdom } \\
\text { sample } \\
\text { Non- }\end{array}$ & 100 & 77 & 39 & $50 \cdot 6$ \\
\hline re-invited & 23 & 9 & 5 & $55 \cdot 5$ \\
\hline Total & & 86 & 44 & $51 \cdot 2$ \\
\hline
\end{tabular}

In the infected group 22 were symptomatic and nineteen asymptomatic ( 46.3 per cent.). In the non-infected group $23(60.5$ per cent.) of 38 , were asymptomatic.

Low abdominal pain was the most common symptom: 39 per cent. in the infected group and 26.3 per cent. in the non-infected group. The incidence of dysuria and vaginal discharge was closely similar in the two groups. $\chi^{2}$ tests indicate that the groups with and without gonorrhoea are not significantly different in regard to individual symptoms or symptoms as a whole.

\section{Discussion}

A considerable number of unmarried unemployed women, the so-called femmes libres, live in the small urban areas of Rwanda. To subsist, this group caters for the sexual needs of the male population, asking payment in cash or in kind in exchange for a short sexual relationship. These prostitutes operate in the local bars as dance partners or barmaids. After some years some of them improve their position and work at home.

The prostitutes in Butare are very young: 86 per cent. being between 15 and 25 years old. Verhagen and Gemert (1972) found 91 per cent. in the 16 to 30 year age group in Kenya. The group we examined may be slightly biased towards the younger ages. Those who refused to attend were mostly prostitutes working at home, and older than those working in the bars.

The prevalence rate of 51.2 per cent. for gonorrhoea is very high. For developing countries few com- parable figures exist. Verhagen and Gemert (1972) found a prevalence rate of 35 per cent. in prostitutes attending venereal disease clinics in Kenya, and of 21 per cent. in the selected Mombasa-Timboni prostitutes who attended for monthly check-ups.

In Ibadan, Nigeria (Osoba, 1972), the prevalence of gonococcal infection in prostitutes was 15.8 per cent. (3 out of 19), compared with rates of 5 and 17 per cent. among indigenous symptomless women and female hospital patients respectively. But all the prostitutes took prophylactic antibiotics regularly.

More data exist for prostitutes in industrialized countries, and among these the prevalence of gonorrhoea is also high. A WHO Technical Report (1963) mentions a study by Keighley (1960), who examined 416 prostitutes and found gonorrhoea in 33 per cent, and in 48.9 per cent. of the 15 to 20 -year age group. In Japan in a group of prostitutes not under medical supervision a prevalence of $42 \cdot 2$ per cent. was found.

A leading article (Lancet, 1968) stated that, of 362 prostitutes examined at Holloway Prison in London in 1966, 21 per cent. had gonorrhoea. Wren (1967) found a prevalence of 44 per cent. at the State Women's Reformatory in New South Wales.

The prevalence in the Butare prostitutes is thus extremely high, particularly if we take into account the sensitivity of the Thayer-Martin culture test. Schmale, Martin, and Domescik (1969) give data which suggest that 6 to 8 per cent. of the females who are infected will have negative cultures (four sites cultured: urethra, cervix, vagina, and rectum). Lucas, Price, Thayer, and Schroeter (1967) established that 92.3 per cent. of patients in whom gonorrhoea was diagnosed by Thayer-Martin culture or by the delayed fluorescent antibody test had positive Thayer-Martin cultures with specimens from one or more sites (urethra, vagina, and cervix). Applying this sensitivity rate of the Thayer-Martin culture to our study, the prevalence of gonorrhoea reaches about 55 per cent.

A basic obstacle to gonorrhoea control is the asymptomatic nature of the infection in about 90 per cent. of infected females (Pariser, 1972).

TABLE III Prevalence of symptoms in women with and without gonorrhoea in a random sample of 79 prostitutes

\begin{tabular}{|c|c|c|c|c|c|}
\hline \multirow{2}{*}{ Symptoms } & \multicolumn{2}{|c|}{ Gonorrhoea (41) } & \multicolumn{2}{|c|}{ No gonorrhoea (38) } & \multirow{2}{*}{$x^{2}$} \\
\hline & No. & Per cent. & No. & Per cent. & \\
\hline $\begin{array}{l}\text { Dysuria } \\
\text { Low abdominal pain } \\
\text { Vaginal discharge }\end{array}$ & $\begin{array}{r}6 \\
16 \\
8\end{array}$ & $\begin{array}{l}14 \cdot 6 \\
39 \cdot 0 \\
19 \cdot 5\end{array}$ & $\begin{array}{r}6 \\
10 \\
5\end{array}$ & $\begin{array}{l}15 \cdot 8 \\
26 \cdot 3 \\
13 \cdot 1\end{array}$ & $\begin{array}{l}\chi^{2}=0.015 ; P=0.9 \\
\chi^{2}=1.44 ; 0.3<P<0.2 \\
\chi^{2}=0.62 ; 0.5<P<0.3\end{array}$ \\
\hline $\begin{array}{l}\text { 'Symptomatic', } \\
\text { 'Asymptomatic' }\end{array}$ & $\begin{array}{l}22 \\
19\end{array}$ & $\begin{array}{l}53 \cdot 7 \\
46 \cdot 3\end{array}$ & $\begin{array}{l}15 \\
23\end{array}$ & $\begin{array}{l}39 \cdot 5 \\
60.5\end{array}$ & $\chi^{2}=1.60 ; P=0.2$ \\
\hline
\end{tabular}

No information obtained from seven subjects ( 3 with and 4 without gonorrhoea) 
About 54 per cent. of the prostitutes in this study who had gonorrhoea declared that they had symptons, but these were not at all specific for the infection; the infected group did not have these symptoms significantly more frequently than the non-infected group. This accords with the findings of Cave, Bloomfield, Hurdle, Gordon, and Hammock (1969) who noted symptoms in 72.2 per cent. of women with gonorrhoea in an obstetrics and gynaecological clinic, but nearly the same frequency of symptoms in patients without gonorrhoea.

At the venereal disease clinic of the Institute, 93.5 per cent. of the infected males indicate prostitutes as their source of infection. In a 9-month study among university students in Butare (Meheus, 1973), we found the incidence of gonorrhoea to be 55.2 per cent.; 98.2 per cent. had contracted the disease from prostitutes. WHO (1963) stated that, in most regions of Africa, 80 to 97 per cent. of gonorrhoea infections were acquired from prostitutes. Ongom and others (1971) recorded a low number of prostitutes as contacts at Kasangati, Uganda, but the contacts were usually referred to as 'girl-friends'.

As prostitutes in Butare form a large pool of highly promiscuous infected women, gonorrhoea control in this group is of major importance in the prevention and control of the disease in the general population. At the Institute, prostitutes attend weekly for a session of health education, and social workers try to persuade them to come monthly for medical examination and routine culture tests.

A regular check-up of prostitutes is necessary, but it is very often less efficient than might be expected, because of the high risk of re-infection and the very high mobility of this group between one town and another.

\section{Summary}

Gonorrhoea is highly endemic in prostitutes, but reliable data are scarce for developing countries. We randomly selected a sample of 100 prostitutes, the so-called femmes libres, in the small town of Butare, Rwanda. 86 of them agreed to be examined.

As elsewhere in Africa, these prostitutes, working as barmaids and dance-partners in the local bars, are very young: 86 per cent. were aged between 15 and 25 years.

The prevalence of gonorrhoea, based on one culture of urethral, vaginal, and cervical specimens, was 51.2 per cent.

Prostitutes with gonorrhoea had symptoms in 54 per cent. of cases, but this was not significantly more frequent than in those without gonorrhoea.

The prevention and control of gonorrhoea in
Butare requires the control of the disease in prostitutes, who are nearly always cited as the source of infection.

\section{References}

ARYa, O. P., and BenNetT, F. J. (1967) Brit. F. vener. Dis., 43, 275

Bennett, F. J. (1962) E. Afr. med. f., 39, 332

Cave, V. G., Bloomfield, R. D., Hurdle, E. S., Gordon, E. W., and Haмmock, D. (1969) F. Amer. med. Ass., 210, 309

KeIGHLEY, E. (1960) Lancet, 2, 253

Kibukamusoke, J. W. (1965) Trans. roy. Soc. trop. Med. Hyg., 59, 642

LEADING ARTICLE (1968) Lancet, 1, 675

Lucas, J. B., Price, E. V., Thayer, J. D., and Schroeter, A. (1967), New Engl. f. Med., 276, 1454

Merteus, A. Z. (1973) Ann. Soc. belge Méd. trop., 35, 179.

Ongom, V. L. (1970) E. Afr. med. f., 47, 479

-, Lwanga, V. N., Mugisha, J. K., and Mafigiri, J. T. (1971) Ibid., 48, 367

OsobA, A. O. (1972) Brit. F. vener. Dis., 48, 116

Pariser, H. (1972) Med. Clin. N. Amer., 56, 1127

Schmale, J. D., Martin, J. E., and Domescik, G. (1969) 7. Amer. med. Ass., 210, 312

Verhagen, A. R., and GEMERT, W. (1972) Brit. F. vener. Dis., 48, 277

World Health Organization (1963) Expert Committee on Gonococcal Infections. First Report. WHO Tech. Rep. Ser., No. 262. WHO, Geneva.

Wren, B. G. (1967) Med. F. Aust., 1, 847

Prévalence de l'infection gonococcique chez des prostituées dans une ville d'Afrique Centrale

\section{SOMMAIRE}

La blennorragie est hautement endémique chez les prostituées, mais nous avons peu de données valables pour les pays en voie de développement.

Dans la ville de Butare, Rwanda, nous avons examiné 86 sujets d'un échantillon aléatoire de 100 prostituées ('femmes libres'). Ces prostituées, qui fréquentent surtout les bars locaux, constituent, comme partout en Afrique, une population très jeune: 86 pour cent entre 15 et 25 ans.

En se basant sur une culture de sécrétions, prélevées au niveau de l'urèthre, du sac postérieur du vagin et du col de l'utérus, une prévalence de l'infection gonococcique de $51 \cdot 2$ pour cent s'est établie.

Les prostituées infectées avaient des symptômes dans 54 pour cent des cas, mais ce pourcentage n'est pas statistiquement différent de celui trouvé dans le groupe non infecté.

La prévention de l'infection gonococcique à Butare exige le contrôle de l'infection chez les prostituées, qui sont presque exclusivement signalées comme source de contamination. 